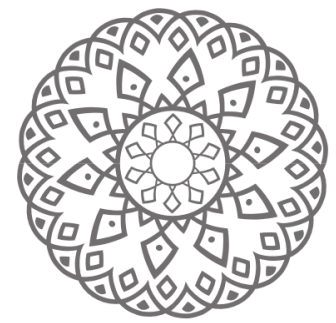

\title{
Subhat Income of Sharia Financial Institutions AcCording to DuAl LAW (Formal and Sharia LaW)
}

\author{
Nurhadi
}

\begin{abstract}
Abstrak: Abstrak: Artikel ini mengkaji dana non-halal dalam bisnis keuangan Islam, dan menganalisisnya berdasarkan filosofi hukum Islam. Metode penelitian yang digunakan adalah metode deskriptif kualitatif, dengan mengandalkan penelitian kepustakaan. Data dianalisis menggunakan analisis isi (content analysis) dengan mengukur manfaat materi berdasarkan filosofi hukum Islam. Penelitian ini menemukan bahwa dana non-halal adalah pendapatan yang berasal dari bisnis non-halal (al-kasbu al-ghairi al-masyru'), yang digunakan untuk kepentingan umat atau kepentingan masyarakat. Berdasarkan ulasan filosofi hukum Islam, penelitian ini menyimpulkan bahwa jika keseluruhan dana didominasi oleh yang halal, makan keseluruhannya menjadi halal. Namun demikian, jika dana halal memiliki proporsi yang sama atau kurang dari dana yang tidak halal, maka yang tidak halal tersebut harus dikeluarkan. Sementara itu, sisa dana menjadi halal berdasarkan prinsip umum al-balwa (kesulitan yang meluas), raf'ul haraj wal hajah al-ammah (mengangkat beban untuk kepentingan umum), muro'at qowa'id al-katsrah wa al-ghalabah (standar hukum lebih dominan) dan tafriq shafqah (memisahkan transaksi halal dari yang haram).
\end{abstract}

Kata kunci: pendapatan, subhat, institusi, keuangan, syariah 
Abstract: The paper aims to analyze the non-halal funds in Islamic finance businesses, and review them based on the philosophy of Islamic law. This research uses a descriptive qualitative method, relying on library research. Data is analyzes using content analysis by measuring the benefit of a mater based on Islamic law philosophy. The result is that non-halal funds are any income originating from non-halal businesses (al-kasbu al-ghairi al-masyru'), used for the benefit of the ummah or the interests of the community. Based on the review of Islamic law philosophy, this study concludes that if the halal funds are dominant, then the funds become halal entirely. On the other hand, if the halal funds have a similar proportion or less than the illicit ones, then the illicit funds should be excluded. Meanwhile, the remaining funds are lawful based on the principle of umum al-balwa (widespread hardship), raf'ul haraj wal hajah al-ammah (lift burden for public necessities), muro'at qowa'id al-katsrah wa al-ghalabah (meaning that legal standards are more dominant) and tafriq shafqah (separating halal transactions from those haram).

Keywords: revenue, subhat, institution, finance, sharia 


\section{Introduction}

In Indonesia, the initiation of Islamic banking in Indonesia was inspired by legal concept in Law No. 7 of 1992 on Conventional Banking. This law is then interpreted by Government Regulation No. 72 of 1992 on Profit Sharing, which was amended by Law No. 7 of 1992 and Law No. 10 of 1999 on Banking (Dual Banking System) (Nasution et al. 2010: 191). This law after that revoked by Government Regulation No. 30 of 1999 on Banking and refined by Law No. 21 of 2008 on Sharia Banking.

Islamic banking is a financial institution that has functions to collect funds, distribute funds, and offer other services offered in conventional banks. Islamic banking is operated using sharia principles issued through fatwa of the National Sharia Council (Dewan Syariah Nasional/ DSN). This institution aims at improving people's lives and the welfare of society (Nadiyyah et al., 2016: 483). In practice, not all Islamic banking institutions can fully adopt sharia principles, because financial industry, in general, is not all based on sharia and dominated by the conventional ones. Moreover, the existing regulations are inadequate due to the lack of interest from the rulers and political elites.

Islamic banks are part of the national banking system that base their operation on Islamic law, as well as a form of a modern bank. The Islamic banking system was developed in the first century of Islam, using the concept of risk-sharing and eliminating certainty based finance and pre-determined profits. In the modern context, Islamic banks become modern financial institutions with the main activities to provide credits or financing and

Islamic banks are part of the national banking system that bases its operations on Islamic law. Islamic banks are a form of modern banks based on legitimate Islamic law, developed in the first century of Islam, using the concept of risk-sharing as the main method, and eliminating finance based on certainty and predetermined profits, also Islamic banks are modern financial institutions whose main activities provide credit (financing) and other services in payment and money circulation (Wibisono, 2012; Utomo, 2017: 1-2).

Financing in Islamic banking becomes the central economic activity for people who suffer from fund (capital) deficiency to continue and develop their economy (Arifin, 2016: 200). The economic wheel of a 
country is often determined by banking institutions as the centre of the digital economy in the modern world (Suhendi, 2011: 287).

Among the incomes of Islamic banks in Indonesia come from mudarabah transaction or contracts between the banks and customers of mudarib. According to Yusuf Qardhawi, mudarabah is a real form of financing which is indirect as a form of rejection of the interest system (riba) applied by conventional banks in seeking profits (Qordhawi, 2010: 184-185).

The interest received by sharia financial institutions from their conventional business partners is tolerated with the consideration of akhaffu dararain (taking smaller harms/ disadvantages) when compared to the use of these funds by non-Islamic institutions (Antonio, 2009: 133-134).

In conducting its business, Islamic banks cannot be completely detached from conventional banks. Some examples are non-halal giro funds from other banks, ta'zir or fine caused by the delays in financing, etc. These non-halal funds can be detected by accounting science. This will inform the portions of funds that are not considered pure Islamic bank incomes, or subhat incomes (non-halal incomes) (Wiyono, t.th: 158-160).

The difficulty of avoiding dependency on conventional business is also caused by insufficient regulations. The question, then, will the nonhalal funds accepted by the Islamic banks jeopardize the sustainability and the welfare of the Islamic banks? At the same time, there is a need to clarify the status of the non-halal funds through regulation to avoid the assumption that Islamic banks are similar to conventional banks. This, in turn, can damage the reputation of Islamic banks and negatively impact their growth and development (Utomo, 2017).

Based on the above explanation, this paper aims at answering questions such as: what do non-halal funds mean? How does Islamic legal philosophy view the non-halal funds or subhat funds received by sharia financial institutions?

\section{Theoretical Framework}

\section{Islamic Financial Institutions}

Islamic financial institutions (LKS) are institutions that use and impose Islamic principles in their business activities such as collecting 
or disbursing funds. These principles include buying and selling and profit-sharing (Karim, 2000: 32).

The basic philosophy of the financial institution is to seek Allah's contentment to obtain virtue in the world and hereafter. Therefore, an Islamic institution must avoid every activity that may lead to the deviation against Islamic values (Lubis, 2004: 34).

The Quran does not explicitly mention financial institutions. However, the Quran emphasizes on the concept of an organization such as a financial organization. The Quran gives considerable attention to the basic concept of muamalah contract with various forms of activities. Related to a political system, for example, the term qaum (community) is used to indicate the existence of social groups interacting with one another. Modern organizations also consider the concept of organization system (Lubis, 2004: 35).

The guideline for the operations of sharia financial institutions is the Quran Sura al-Baqarah, verse 275 concerning the compulsion to stay away from riba (usury) and to implement the profit sharing and trade system (Ministry of Religion of the Republic of Indonesia, 1997: 63).

In the Islamic financial system, non-banking institutions have a similar role with banks. The difference lies in principle and operational mechanism. With the elimination of interest system (riba) in direct or indirect investment, the practice of interest-free systems is easier to be implemented integrally. Therefore, the non-bank financial institutions accommodate the needs of the society that are not yet fulfilled by Islamic banking services. (Sudarsono, 2003: 7-8).

\section{Sharia Banking Theory}

Islamic banks are financial institutions with the main business to provide credit and other services in payment and money circulation based on sharia principles (Sudarsono, 2004: 27; Zhafirah et al., 2017: 9-14). Sharia banking is every aspect related to sharia banks and sharia business units, including institutions, business activities, methods and processes in carrying out their business activities (RI Law NO.21 of 2008 concerning Sharia Banking Chapter 1 Article 1).

Sharia principles are rules of the agreement between banks and 
other parties related to funding deposits, financing or other activities carried out based on Islamic principles (Rivai, and Veithsal, 2008: 90).

An Islamic bank is a new phenomenon in the modern economic world. The emergence of Islamic bank originated from vigorous efforts carried out by Islamic experts to support Islamic economic system. It is stated that Islamic banking is everything related to Islamic banks and Sharia Business Units (Unit Usaha Syariah/ UUS). Similar to the conventional banks, Islamic banks also maintain three main functions, namely receiving deposits, lending money and providing money transfer services (Law Number 21 of 2008 concerning Islamic Banking).

Islamic banking products can be divided into three. The first is Fund Distribution Products. In distributing funds for customers, Islamic finance products are divided into four types based on the principle used (Karim, 2004: 98), which include 1) Products using sale (bay') principles: Murabaha financing (Karim: 99), salam financing and istisna financing; 2) Products using lease principles; 3) Products using profit-sharing principles (shirkah): musharakah financing (Karim: 99-100) and mudarabah financing; 4) Complementary Contract Principles: Hiwalah (Transfer of Debt), Rahn (Pawn) (Rivai, and Veithsal, 2008: 90), Qard (Loan), Wakalah (Representative) and Kafalah (Bank Guarantee) (Zuhri, 1993: 169).

The second is fund collection products. Two principles applied in fund collections are the principles of wadi'ah and mudarabah. The third is service products, consisting of Sharf (Foreign Exchange Sale) and Ijarah (Rent).

Of the three Islamic banking products above, in general, they still have a relationship with conventional banking. This is because of the absence of regulations that required the full implementation of sharia, including the absence of sharia-based central bank (Bank Indonesia) and the establishment of sharia business units by conventional banks. Even though the business units are operated based on sharia principles, their initial capitals come from their parent banks. In this case, the mixing of halal funds and non-halal funds becomes difficult to be avoided. 


\section{Literature Review}

There are several studies related to halal funds in Islamic financial institutions. First is the study by Syifa Nadiyyah, Neneng Nurhasanah and Nunung Nurhayati, entitled Islamic Law Review on income and non-halal fund distribution at PT. Bank Syariah Mandiri. This study examines the non-halal incomes received by a sharia bank, which in this case, PT Bank Syariah Mandiri. It is found that the use of nonhalal funds in PT. Bank Syariah Mandiri is based on the principle of akhaffu dararain rule (taking smaller disadvantages) by comparing with the use of the funds by non-Islamic financial institutions.

The second is the study by Erina Maulidha and Ai Nur Bayinah, entitled Framework for Disclosure of Non-Halal Transactions in Islamic Banks (Proceedings of the Challenges On the Islamic Accounting, Snas, 2014). This study proposes that non-halal funds in Islamic financial institutions must be fully disclosed in the notes to financial statements or annual reports as a part of public transparency efforts.

The third is Ahmad Roziq and Widya Yanti's study on Recognition, Measurement and Presentation of Halal Funds in Financial Statements of Amil Zakat Institutions (Jember Accounting Journal, Accounting Study Program, Faculty of Economics, University of Jember, nd.). This study finds out that the non-halal funding sources in zakat institutions have been supported by PSAK 109. Moreover, the using of the halal funds is still very high due to the dependency level of the zakat institutions on conventional banks.

The next is the study of Nur Hisamuddin and Iva Hardianti Sholikha on the perception, presentation and disclosure of non-halal funds in the National Zakat Institution and PKPU of Lumajang Regency (Zakat and Waqf Journal, Lecturer in Accounting Department FE UNEJ Jember, nd.). The study insists that the transfer of non-halal funds from conventional banks to the National Zakat Institution and PKPU is considered acceptable. This is because the funds are allocated for social purposes. The National Zakat Institution of Lumajang has not disclosed any policies regarding the acceptance and distribution of non-halal funds.

After that is the study of Huzain Sholeh Utomo, a Study of NonHalal Revenue and the Impact of Its Use on the Reputation and Trust 
of Customers of Islamic Banking (Empirical Study at Bank Muamalat) (Thesis of the Faculty of Economics and Islamic Business Alauddin Islamic University Makassar, 2017). This study found that the nonhalal funds were only obtained from the accounts related to other banks. This is, however, affected the bank's reputation among the customers.

The last is the study of Arianto Saputra, Analysis of Ta'zir and Ta'widh Fund Management for Customers Default at PT. Bank Rakyat Indonesia Syariah (Thesis Sharia Banking Concentration Muamalah Study Program (Islamic Economics) Faculty of Sharia and Law Syarif Hidayatullah State Islamic University Jakarta, 2014). This study reveals that ta'zir is liable to those who are capable but reluctant to fulfil their responsibility, whereas ta'widh is for negligent customers. Moreover, ta'zir does not include property incomes (non-halal income) while ta'widh is part of Islamic bank incomes.

The above studies reveal empirical evidence on the existence of halal funds in Islamic banking institutions. This particular study, on the other hand, focuses on the theoretical inquiries related to the Islamic legal scholars' opinions and Islamic legal philosophy on non-halal funds. In this study, the concept of maslahah and maqasid sharia are used as the theoretical frameworks taken from Islamic legal philosophy.

\section{Literature Study}

\section{Islamic Accounting}

Accounting science, according to Islam, deals with the recognition, recording and transactions as well as the presentation of wealth and obligations. In the Quran Surat al-Baqarah verse 282, Islam regulates accounting (Ministry of Religion, 2009: 70). There are principles and standards of accounting in sharia, which is related to its objectives. These principles are (Roziq and Yanti, nd.: 23): 1) the principle of accrual-based recording; 2) the use of market prices or fair prices; 3) materiality determined by sharia indicators; 4) Full disclosure of information both quantitatively and qualitatively and reducing misinterpretation; 5) data validity and reliability (data reliability); 6) consistency in applying standards; 7) harmonization of principles so that they can be compared (comparability); 8) presenting information about the entity's financial performance; 9) presenting information about corporate social responsibility, including attention to the poor 
(needy and poor); 10) presenting information relating to obedience to sharia (upholding justice, paying zakat, and strictly avoid injustice, speculation, usury, gambling, and uncertainty).

In the Muslim world, the attempt to standardize Islamic accounting principles is through AAOIFI (The Accounting and Auditing Organization for Islamic Finance Institution), an international organization for Islamic finance. In Indonesia, the Islamic accounting standards are formulated by IAI through its Financial Accounting Standard Board. This board issues PSAK or Statement of Financial Accounting Standards (Roziq and Yanti: 23).

\section{Philosophy of Islamic Law}

Philosophy of Islamic Law consists of 3 words, namely Philosophy, Law and Islam. Each of the three words has its own definition. Before examining the meaning of Philosophy of Islamic Law, it is important to the individual meaning of these three words (Ash-Shidieqie, 2003: 54). The philosophy of Islamic law is a special philosophy with Islamic law as its object. The objective of such philosophy is to analyze Islamic law methodically and systematically to obtain fundamental information or analyze Islamic law scientifically with philosophy as its tool (Djamil, 2009: 14).

So the essence of the philosophy of Islamic law is the knowledge of the nature, secrets, and objectives of Islamic law both concerning its material and its designation process. In other words, the philosophy is used to transmit, strengthen, and maintain Islamic law to maintain its main purposes in related to purposes set by Allah, which is to create welfare of humankind (benefit). With the philosophy of Islamic law, it is expected that the law is adaptable by the current situation and conditions (Djamil, 2009: 14; Ash-Shidieqie: 55). In other words, the philosophy of Islamic law becomes an effort to deal with emerging issues in the contemporary world with a critical approach. It can be said that the philosophy of Islamic law is the art of criticism, in the sense that every issue is open to discussions and debates (Ash-Shidieqie: 55).

The philosophy of Islamic law, like other philosophies, respond to questions that are not yet found in legal books. Therefore, the main tasks of the philosophy of Islamic law are: 1) critical tasks to question 
the established paradigms in Islamic law; and 2) constructive tasks to connect the branches of Islamic law (Praja, 2005: 15).

\section{Research Methods}

This is qualitative research (Meleong, 2011: 29) focusing on literature inquiries (Muhajir, 1996: 169; Bugin, 2008: 121; Sugiono, 2005: 329; Zeid, 2004: 1). Data used in this study comes from works of Islamic legal scholars on Islamic legal philosophy and works on the philosophy of science and logic. The results are analyzed using content analysis method (Kriyantono, 2010: 232-233; Kholil, 2006: 51; Umar, 2002: 44), with the framework of philosophy of science (Muhajir, 1989: 76 -77) and logic (deductive \& Inductive) (Affan, 2002: 1).

\section{Results And Discussion}

\section{The Nature of Subhat Income (Non-Halal Funds) and Its Origin}

Non-halal assets are divided into two: 1) assets that are forbidden because of its unclean essence (haram lizatihi), such as alcoholic beverages, pork and others (Maulidha and Bayinah, 2014: 179); and 2) non-halal funds come from non-halal businesses (Al-Kasbu AlGhairi Al-Masyru ') (IIIT Team, tz.z; 62; Juhali, 2013: 72) such as money resulted from interests in loans, gambling, bribery, corruption, alcoholic beverage and pork sales (Maulidha and Bayinah: 179). Fatwa of DSN-MUI explains that there are several activities that are forbidden by Islamic law, namely: 1) Business from conventional financial institutions (banking and insurance); 2) the investment in which the riba dominates the capital in the level (nisbah) of company's debt to other financial institutions; 3) businesses which contain gambling and illegal trade; 4) producing and distributing forbidden goods (i.e. alcoholic beverages and pork); 5) producing and distributing goods and services that lead to moral destruction or dangers (Indonesian Ulama Council, 2006: 274).

The DSN fatwa explains such type of business activities generally occur in the Stock Exchange. Therefore, non-halal businesses are not limited to those five businesses, but there are many others. These businesses consist of riba, sharf (addition), speculation, fraud and bribery. 


\section{Use of Subhat Fund (Non-Halal Fund)}

Islamic legal scholars agreed that the are three important matters related to the discussion of non-halal funds: 1) Non-halal income is illegitimate, therefore it cannot be used by the owner (the illicit business actor) for any needs (hajat), either openly or by means of hilah (legal tricks), such as being used to pay taxes; 2) business capital remains halal if it is sourced from a lawful business; 3) non-halal income must be given or distributed to other parties as alms.

The AAOIFI in Bahrain explains that sharia standard is as follows: "non-halal income may not be used for any activity, even though it used the way of hilal, such as to pay taxes" (Oni Sahroni, 2010: 293-294).

According to fiqh (Islamic jurisprudence): "any income that cannot be owned, they cannot be given (to other parties)". Likewise, as explained in the fatwa books of the ulama (Al-Fatawa and An-Nazawi), the scholars had different opinions about the objects or parties receiving non-halal funds. The differences are as follow:

1) The majority of scholars argue that non-halal funds may only be channeled to public facilities (al-mashlalih al-ammah), such as the road construction or other public facilities.

2) Some scholars, such as Sheikh Yusuf al-Qardhawi and Prof. Dr. al-Qurrah Dagi, argue that non-halal funds may be channelled to all social needs such public facilities (al-mashalih al-ammah), or for consumptive purposes of the needs, including community empowerment programs (Roziq and Yanti: 26).

This paper argues that the source of the differences in the above opinions is the status and ownership of the donated funds. Islamic legal scholars who allow the distribution of non-halal funds only for public facilities based their opinion on the view that the illicit funds are forbidden for the owners and their recipients. If the funds are forbidden to the recipients, then, they should not use the funds for their personal needs. However, they must give the funds for public interests, such as road construction, which in the end, will be owned by the community in general.

For scholars who allow the distribution of non-halal funds based their view on the belief that the illicit funds are forbidden for the owners, but halal (lawful) for the recipients. If the funds are lawful for the 
recipients, then, they can use them for their personal needs, including consumptive activities and community empowerment programs. This second view is based on what can be found in nass (divine decree or textual proof) and the principle of maqashid or Islamic legal philosophy. The first is the hadith of the Prophet Muhammad when his wife Aisha R.A. cooked lamb meat given to her by Shahabiyyah Barirah, while Sahabiyyah Barirah got the lamb meat from charity. The Prophet asked Aisha about the meat; the Aisha said: This meat is form charity, and the Messenger of Allah does not take charity. Then the Prophet said: Indeed, this item is a charity for her, but a gift for us." This hadith implies that the non-halal funds can be channelled and consumed by the recipients of the charity, such as the needs.

The second proposition is based on the story of Atsar Al-Hasan. $\mathrm{Al}$-Hasan once was asked about the repentance of al-ghal (people who took the booty (ghanimah) before its distribution or before the troops dispersed). Al Hasan replied: "they (al-ghal) must give alms to the treasurer."

The third proposition is regarding mashat: 1) non-halal funds do not belong to certain parties but are public property. As long as the funds are not owned by a particular person or party, then the funds can be channelled to poor people and those in need. 2) Non-halal funds are forbidden for the owner, but when ownership changes occur, the status of the funds is halal for the recipient, both private entities such as the poor, or institutional entities such as social foundations. 3). The community empowerment program distributes the funds for longterm goals so that the benefits received are greater and have long-term impacts (fiqh muàmalat and fiqh aulawiyyat).

Yusuf Al-Qaradawi explained: "In my opinion, non-halal funds are dirty (khabits) and unclean for those who get them, but it is lawful for (recipients, such as) people in need and social needs. This is because the funds are not forbidden due to its matter, but due to the parties and other actors.

The more important is to distribute non-halal funds to matters that are beneficial for Muslims, rather than for non-Muslims, who may use the funds for something forbidden according to the teaching of Islam (Aziz and Ulfah, 2011: 53). 


\section{Subhat Income (Non-Halal Fund) in Islamic Philosophy Perspective}

In general, there are two opinions of ulama concerning the issue of subhat incomes (Syahatah, nd: 9). First, some scholars argue that the mixing of halal funds and non-halal funds are illegal. The Islamic Jurisprudence Institute of the Organization of Islamic Conference (OIC) is among those who argue that the fund is categorized as illicit funds. Institutional Jurisprudence Decree No. 7/1/65 at the $7^{\text {th }}$ meeting states that there are no differences in the view that shares from a company which its main business is illegitimate businesses (contain riba, illicit goods, and other forbidden businesses) are not halal (illegitimate). Consequently, it is forbidden to buy shares for a company that sometimes uses illicit transactions in their businesses, even though its main activities are halal.

This view is based on the argument (ijtihad/ istishad) in fiqh, such as: "If there is a mixing between halal and subhat funds, then the funds become illicit". According to this fiqh rule, if the halal funds mix with illicit funds, then the law of haram is more favorable than the halal. This means that the whole funds are considered illicit (AsSuyuthi, 1418 H / 1998 M; Al-Himawi, 336; Husein Syahatah and 'Athiyah, 22: Wzaratu al-Auqaf wa al-Syu'ni al-Islamiyah, nd: 76). This argument is also supported by the hadith concerning subhat, from Abu Abdullah An-Nu'man bin Bashir. He said: I heard the Messenger of Allah said: "Verily the lawful thing is clear and the unclean is also clear, and between the two there are vague things. Most humans do not know it. He, who avoids the vague, has guarded his religion and honor. And whoever falls into a vague matter, the, he has fallen into an unlawful matter, like a shepherd who is near to someone else's fence, who concerns that someone will enter it. Know that every king has a fence (rules); God's rule is His prohibitions. Indeed, in a body, there is a lump of flesh. If it is good, so is the whole body. If it is damaged, so is the whole body. Know that it is the heart" (Narrated by Bukhari and Muslim).

Second, some scholars argue that if halal funds are more dominant than non-halal funds, then the entire funds become halal (Al-Barakah, 2003: 306; As-Syaukani, 1428 H / 2007 M: 89; Al-Maliki, 439 H; Ad-Dardir, nd: 15; Ar-Rafi': 420H; Taimiyah, nd: 48). The scholars based their view on the following principles. The first is the Islamic 
jurisprudence stating that "the majority law is the same as the whole law (Al-'Ibadi: 303; Nasution: 183). The second is the principle of maslahah (al-hajah al shar'iyyah). There is a need for Islamic companies to avoid businesses with usury in upholding their businesses, and provide an alternative form of lawful businesses (Al -'Ibadi, t.th: 303; Nasution, 1423 H / 2003 M: 183).

Some scholars, including Ibn Nujaim, further explained: "if halal funds mix with illicit funds in a country, then the funds can be taken, unless there is evidence that the funds are illegal" Nujaim, nd: 345). Imam An-Nawawi explained as follows: "If it happens in a country that unlimited illicit funds mix with limited halal funds, then the funds can be taken unless there is evidence that the funds are haram. If the evidence does not exist, then the funds are not haram. However, abandoning that matters (illicit fund) is lovable to Allah. Every illicit fund should be treated with force" (Al-Ansari, nd. 418; Az-Zarkasyi, 1993: 342). Furthermore, Ibn Taimiya explains: "As for a person who carries out a transaction with riba, then the transaction is mostly considered halal unless it is known that most of the transaction is markuh (disliked or offensive). If someone sells a 1000 worth good with the price of 1200 , then the illicit part is only the margin. If someone obtains incomes consisting of halal and haram funds, then the halal part is not forbidden. He can take the halal part as if the funds are owned by two shariks (partners). In shirkah (partnership), the funds are mixed and belong two both parties. So the funds can be divided between them.

This paper argues that the strongest (rajih) opinion is the second opinion confirming that: 1) if the halal funds are dominant, then all of the funds will be halal. 2) If the halal funds have the same proportion as the illicit funds or fewer, then the percentage if the illicit funds must be excluded. While the remaining funds are lawful, this second opinion is more appropriate because of several reasons. The first reason is general al balwa, meaning that the mixed funds are difficult to be avoided in business activities or other activities. The second is Raf'ul Haraj wa Hajah Al-Ammah (minimizing difficulties and fulfilling public needs). Among other examples is the economic institutions and environment that are still not Islamic due to unsupportive regulations, communities that do not understand sharia economics, the domination of 
conventional industries. In this case, non-Islamic transactions become unavoidable (Al-Marthan, nd: 33-34).

The third reason is Muro'at Qowa'id Al-Katsrah Wa Al-Ghalabah, meaning that legal standards are more dominant (Nujaim, nd: 112-114; Al-Quratubi, nd: 194-195; Al-Zarkasyi, nd: 235; Al-Kasani, nd. 144). The last is fiqh rule about tafriq shafqah (separating halal transactions from illicit transactions) (Ar-Rajihi Company Sharia Supervisory Board Decree No. 485 dated 23/8/1422 H.).

\section{Conclusion}

Subhat income or non-halal funds are any income derived from non-halal businesses (Al-Kasbu Al-Ghairi Al-Mayru) such as interests (riba), gambling, bribery, corruption, buying and selling liquor or pork, and buying and selling with speculation, sharf (addition), and fraud. Based on the examination of Islamic legal philosophy, it is found that if the halal funds in dominant compared to the non-halal ones, then the funds become entirely halal. However, if the proportion of the halal funds are the same with or less then the non-halal ones, then the illicit funds must be excluded while the remaining funds are lawful. This is based on the principles of General Al-Balwa, Raf'ul Haraj Wal Hajah Al-Ammah, Muro'at Qowa'id Al-Katsrah Wa Al-Ghalabah (meaning that legal standards are more dominant) and tafriq shafqah (separating halal transactions from that are haram).

\section{References}

\section{Journal:}

Maulidha, Erina and Bayinah, Ai Nur. (2014). Kerangka Pengungkapan Transaksi Non-Halal di Bank Syariah. Proceedings of The Challenges On The Islamic Accounting, SNAS, 12 (1), 176-188.

Nadiyyah, Syifa, and Nurhasanah, Neneng and Nurhayati, Nunung. (2016). Tinjauan Hukum Islam Terhadap Pendapatan dan Penyaluran Dana Non Halal pada PT. Bank Syariah Mandiri. Prosiding Keuangan dan Perbankan Syariah : 2460-6561, Accounting Study Program, Faculty of Economics and Business, Bandung Islamic University, 2 (1), 1-20.

Roziq, Ahmad, and Yanti, Widya. (2013). Pengakuan, Pengukuran, Penyajian dan Pengungkapan Dana Non Halal pada Laporan Keunagan Lembaga Amil Zakat, Junral Akuntansi Universitas Jember, Faculty of Economics, University of Jember, 11 (2), 20-47. 
Wibisono, Andri and Rodhiyah. (2012). Analisis Kinerja Keungan pada PT. Bank Muamalat Indonesia, Tbk Periode 2005-2009. Jurnal Administrasi Bisnis, 1 (1), 25-36.

\section{Book:}

Ad-Dardir. (t.th). Hasiyah Ad-Dasuqi Ala Asy-Syarh Al-Kabir. Egypt, Dar al-. Ma'arif, Juz 3.

Affan, Afraniati. (2002). Filsafat Logika. Padang: Azka Padang.

Aji, Ibrahim. (t.th). Community Empowerment, as quoted in, Qararat Wa Taushiyat At-Tabi Al-Fiqhi Al-Islami Majma 'Li Munadzamati Al-Mu'tamar Al-Islami. Cairo: Maktabah ilmiyah.

Al-Ansari, Abi Zakariya. (t.th). al-Mathba'ah al-muniriyah an-Nawawi, Al-Majmu; Syarhu Al-Muhadzdzab. Saudi Arabia Jeddah: Maktabah Irshad.

Al-Himawi. (t.th). Ghamzu 'Uyun Al-Basha. Beirut Lebanon: Maktabah Ilmiyah, Juz 1. Al-Kasani, Alauddin. (t.th). Bada’i Ash-Shana’i. Lebanon: Maktabah Ilmiyah, Juz 6.

Al-Maliki, Ibn Syas. (t.th). Aqdul Jawahir Al-Tsaminah. Morocco: Dar al-hadis, juz 2.

Al-Marthan, Said. (t.th). Dhowabith Taqdim Al-Khadamat Al-Mashrifyah Fi AlBubuk At-Taqlidiyah-Tajribatu Al-Bank Al-Ahli At-Tijari. Beirut: Maktabah Dar al-Kutub.

Al-Quratubi, Abul Walid Muhammad bin Ahmad Ibn Rushd. (t.th). Al-Bayan Watahshil. Beirut: Maktabah Ilmiyah, juz 18.

Al-Zarkasyi, Badruddin Muhammad bin Bahadur. (t.th). Al-Mantsur Fi AlQawaid. Cairo: Darl Ilmi, Juz 2.

Antonio, Muhammad Syafei. (2009). Bank Syariah Bagi Bankir \& Praktisi Keuangan. Jakarta: Tazkia Institute.

Arifin, Zainul. (2016). Dasar-Dasar Manajemen Bank Syariah. Jakarta: Alvabet Library.

Ar-Rafi'i, Imam Abdul Qasyim. (t.th). Daqåiq Ar-Raudhah. Jeddah: Haramain, juz 3.

Ash-Shidieqie, Hasbi. (2003). Filsafat Hukum Islam. Jakarta: Bulan Bintang.

As-Suyuthi. (1418 H / 1998 M). Tahqiq: Muhammad Tamir and Hafidz 'Assyria Hafidz, dar-As-Salam, Al-Asybah Wa An-Nadzair Fi Qawa'id Wa Furu'AsySyafi'iyah. Cairo: Maktabah Ilmiyah.

As-Syaukani, Muhammad bin Ali bin Muhammad. (1428 H / 2007 M). Fath alqadir, (Beirut Lebanon: Darul Ma’rifah, juz 6.

Aziz, Abdul and Ulfah, Mariyah. (2011). Kapita Selekta Ekonomi Islam Kontemporer. Bandung: Alfabeta.

Az-Zarkasyi. (t.th). Al-Bahru Al-Muhith, (Beirut Lebanon: Darul Kutub Ilmiyah, 1413 H / 1993 M), Juz 1 
Burhan, Bugin. (2008). Penelitian Kualitatif: Komunikasi, Ekonomi, Kebijakan Publik dan Ilmu Sosial Lainnya. Jakarta: Kencana.

Djamil, Fathurrahman. (2009). Filsafat Hukum Islam. Ciputat: Logos Wacana Ilmu. Guddah, Abdu As-Sattar Abu. (2003). al-haiah ash-syar'iyah li al-barakah, Majmuatu dallah al-baraka, Al-Musahamah Fi Tata'amalu Bi Al-Fawa'id ArRibawiyah. Jeddah: Darl Ilmi, cet. II.

Haidar, Ali. (1423 H/2003 M). Duraru Al-Hukkam Syarh Majallati Al-Ahkam. Riyadh: darul Ilmi al-Kutub, juz 1.

Al-Ibadi, Abi Bakrin bin Ali bin Muhammad al-Hidadi. (t.th). Al-Jauharah AnNirah. Fakistan: maktabah Haqqoniyah, juz 1.

IIIT Team. (t.th). Mushtalahat Al-Fiqhi Al-Mali Al-Mu'ashir. IIIT.

Majelis Ulama Indonesia. (2006). Himpunan Fatwa Dewan Syariah Nasional. Jakarta, Published by Collaboration with DSN-Bank Indonesia.

Juhali, Wahbah. (2013). Qadhaya Al-Fiqh Wa Al-Fikr Al-Mu'ashir. Beirut: Dar al-Kutub al-Ilmiyah.

Karim, Adiwarman A. (2004). Bank Islam : Analisis Fiqih dan Keuangan. Jakarta: Raja Grafindo.

Karim, Muhammad Abdul. (2000). Kamus Bank Syariah. Yogyakarta: Asnaliter.

Kholil, Syukur (2006). Metodologi Penelitian. Bandung: Citapusaka Media.

Kriyantono, Rachmat. (2010). Teknik Praktis Riset Komunikasi. Jakarta: Kencana Prenada Media Grup.

Lubis, Suhrawardi K. (2004). Hukum Ekonomi Islam. Jakarta: Sinar Grafika.

Meleong, Lexy J. (2011). Metode Penelitian Kualitatif. Bandung: Remaja Rosdakarya.

Ministry of Religion of the Republic of Indonesia. (1997). Al-Qur'an and Translation. Jakarta: Indonesian Ministry of Religion.

Muhajir, Noeng. (1996). Metode Penelitian Kualitatif. Yogyakarta: Rake Sarasin.

Nasution, Mustafa Edwin, ddk. (2010). Pengenalan Eksklusif Ekonomi Islam. Jakarta: Kencana Prenada Media Group.

Nujaim, Ibnu. (t.th). Al-Asybah Wa An-Nadzair. Egypt: Dar al-Kutub.

Praja, Juhaya S. (2005). Filsafat Hukum Islam. Bandung: Pusat Penerbitan Universitas LPPM.

Qordhawi, Yusuf. (2010). Norma dan Etika Ekonomi Islam. Jakarta: Gema Insani Press.

RI Ministry of Religion. (2009). Alquran dan Terjemahan. Semarang: Toha Putra.

Rivai and Veithsal. (2008). Islamic Financial Management Teori, Konsep dan Aplikasi Panduan Praktis untuk Lembaga Keuangan, Nasabah, Praktisi, dan Mahasiswa. Jakarta: Raja Grafindo Persada.

Sahroni, Oni. (2010). Maqashid Bisnis, as quoted in, Al-Ma'ayirasy-Syar'iyah No. 21 concerning Shares, Hai'atu al-Muhasabahwa al-Muraja'ah li al-Muassasat al-Maliyah al-Islamiyah. Bahrain: Darl Kutub. 
Shaheedah, Hussein. (t.th). Adh-Dhawabith Ash-Shyar'iyah Li Furu Al-Mu'amalat Al-Islamiyah Bi Al-Bunuk At-Taqlidiyah. Jeddah: Haramain.

Sudarsono, Heri. (2004).Bank \& Lembaga Keuangan Syariah: Deskripsi dan Ilustrasi. Bandung: Ekonisia.

Sugiono. (2005). Memahami Penelitian Kualitatif. Bandung: Alfabeta.

Suhendi, Hendi. (2011). Fiqih Muamalat. Jakarta: Raja Grafindo Persada.

Syahatah, Husein and 'Athiyah. (t.th). Adh-Dhowabith Ash-Shar'iyah Li AtTa'amul Bi Suq Al-Auraq Al-Maliah. Cairo: Darl Ilmiyah.

Taimiyah, Ibnu. (t.th). Majmu Al-Fatawa. Riyad: Maktabah alamyah, juz 29.

Umar, Husein. (2002). Metode Riset Komunikasi Organisasi : Sebuah Pendekatan Kuantitaif, Dilengkapi dengan Contoh Proposal dan Hasil Riset Komunikasi Organisasi. Jakarta: Gramedia Pustaka Utama.

Wiyono, Slamet. (2006). Cara Mudah Memahami Akuntansi Perbankan Syariah Berdasar PSAK dan PAPSI. Tangerang : Grasindo

Wzaratu al-Auqaf wa al-Syu'ni al-Islamiyah. (t.th). Al-Mausu'ah Al-Fighiyah AlKuwaitiyah. Beirut: Maktabh al-Kutub, juz 8.

Zeid, Mestika. (2004). Metode Penelitian Perpustakaan. Jakarta: Yayasan Obor Indonesia.

Zhafirah, Zahra Siti, et al. (2017). Perbankan Syariah. Makalah Program Studi Ekonomi dan Keuangan Islam, Fakultas Pendidikan Ekonomi dan Bisnis, Universitas Pendidikan Indonesia.

Zuhri, Moh. (1993). Empat Terjemahan Fiqh Madzab. Semarang: Ash-Syifa.

\section{Thesis/Dissertation:}

Utomo, Huzain Sholeh. (2017).Kajian Pendapatan Non Halal dan Dampak Penggunaannya Terhadap Reputasi dan Kepercayaan Nasabah Perbankan Syariah (Studi Empiris pada Bank Muamalat). (Skripsi oleh Fakultas Ekonomi dan Bisnis Islam UIN Alauddin Makassar). Retrieved from http://repositori.uin-alauddin. ac.id/3464/1/Huzain\%20Sholeh\%20Utomo.pdf. Accessed May 17, 2019 At 8:20 p.m.

\section{Intenet Online:}

Aji, Ibrahim, Community Empowerment According to Islamic Jurisprudence, website. online.http: //mysharing.co/dana-non-halal-untuk-fikih-islam/. Accessed. Dated 2.Januari,2017.Jam20.00Wib.

\section{Nurhadi}

Islamic College (STAI) Al-Azhar Pekanbaru Riau, Indonesia

E-mail: alhadijurnal@gmail.com, alhadicentre@yahoo.co.id 